\title{
Reverse Engineering of Arable Agriculture: The Technique of Tilling and Plowing as an Erroneous Development from the Ancient Technology of Field Desalination of Endorheic Basin Florescent Top-Soils to Produce Playa Salt Cake Employing Qanat Falaj Karez Irrigation Systems
}

\author{
David Bloch* \\ M.R. BLOCH Salt Archive 198 Ben Yehuda Str TelAviv, Israel \\ *Corresponding Author: David Bloch, M.R. BLOCH Salt Archive 198 Ben Yehuda Str TelAviv, Israel.
}

Received: October 03, 2019; Published: November 07, 2019

DOI: 10.31080/ASAG.2019.03.0714

\begin{abstract}
The Qanat, engineered, sophisticated irrigation technology developed more than 3500 years ago, is thought to have begun in the Persian arid zone alluvial basins that were mostly endorheic. The still operating 70,000 of these systems and some 250000 kilometers of tunnels were the sophisticated human development of extended inland salt production from natural coastal "sabkha" evaporation pans. The porous desert sand top soils were ideal for desalinating and leaching the highly saline diapir evaporites to obtain pure layered concentrates, rather than for what has always been assumed was Qanat furrow irrigation of arable crop farming. The ancient priority of salt production farming first over yet-to-be-invented crop farming was mankind's need to preserve the meat of the now domesticated animal livestock. Is clearly demonstrated by today's revised policies of the unnecessary ridge and furrow "plowing", "no-tilling" and fertilizer field technologies. Qanat irrigation may instead even have additionally been the forebearer of "Aquaponic", "Hydroponic" and even "Aeroponic" pyramid farming technology as was thought to have been used in the Hanging Gardens of Babylon and Central Asia.

Keywords: Qanat; Karez; Falaj; Salt; Monopoly; Irrigation; Desalination; No-Tilling; Hydroponic; Leaching
\end{abstract}

\section{Introduction}

Historians have often noted that during the Punic wars the ancient Romans conquered the colony Carthage on the North African "Sabkha" coast and punished the local citizens by "sowing" their fields with salt. Since the area surrounding Carthage is in effect a huge flat "sabkha" where nature has deposited huge quantities of evaporite salts by flooding and precipitation, including the essential for animal life, the chemical compound Sodium Chloride, it begs the question as to whether this was done as punishment or benefit.

Similarly and perhaps in parallel, The Chinese tuntian [屯田], cultivation "fields", were ancient agro-colonies, mostly in the border regions of Tarim basin, North-Western China, formed to supply the Chinese markets with "agricultural" salt products. Most of these communities were staffed with military personnel (juntun 軍屯). civilian agro-colonies served to supply military garrisons. The first of these colonies was created under the reign of Emperor Wu 漢武帝 (r. 141-87 BCE) of the Han dynasty 漢 (206 BCE-220 $\mathrm{CE}$ ), when large amounts of troops in the newly conquered territories protecting the Silk Road trade to the west (the Western Region 西) had to be provided with grain and other foodstuffs. These agro-colonies although isolated oasis,soon developed into the Spice route Aka: The Silk Road. The mountain watershed supplies provided a minimum means of irrigation by Qanat systems.

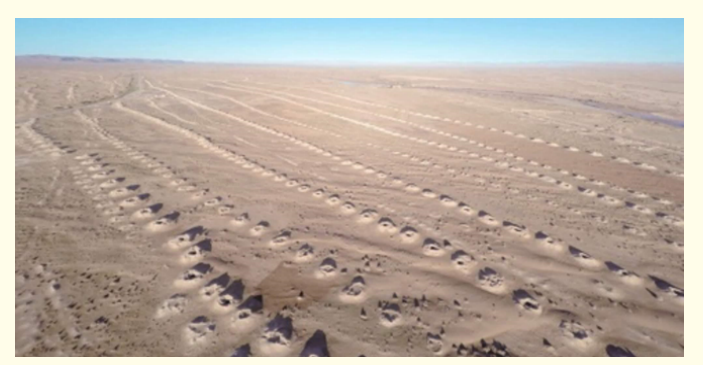

Figure 1: "fields" of Qanat irrigation holes for surge leaching of alluvial sub-florescent soils.

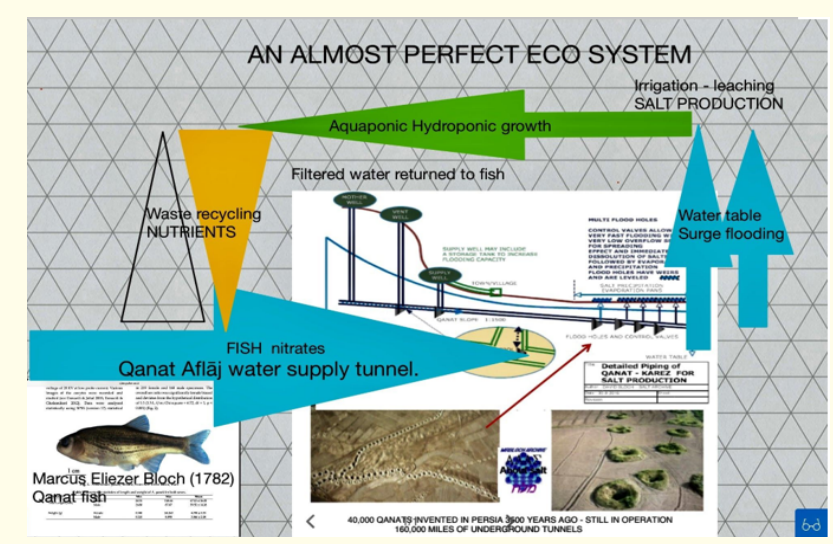

Figure 2: Schematic of Qanat Oasis irrigation systems. 
The use of Qanat Karez Aflaj water streams is still used for domestic irrigation purposes since the Islamic agricultural revolution, however, the human engineering motivation required for building these ancient systems was for a far more important purpose. The surface crust of an inland Sabkha basin typically is made up of layers of different salts that have re-crystalized and settled or precipitated during the evaporation process of controlled QANAT system floodwaters. Leached Salts dissolve quickly in a desert endorheic basin, and the process can produce purer and more concentrated layered playa salt cakes. These various dissolved salts leached and crystalized out of the underlying porous subsoil layers were the original ancient purpose engineered design of the Qanat to control basin flooding without destroying the basin salt mirror playa or causing erosion.

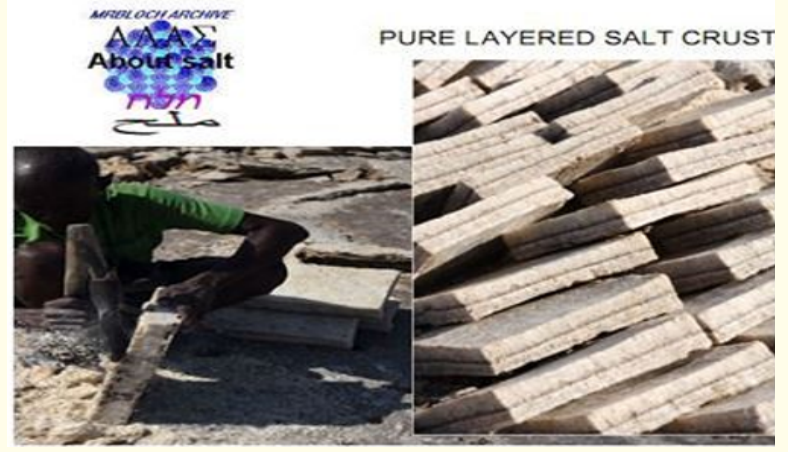

Figure 3: Forming salt crust slabs showing clear microbial layers (salt Archive).

They were built and operated under extreme hardship during certain periods when coastal "Sebkha" salt evaporation pans were globally inundated due to climate change, and salt was catastrophically in short supply. The salt "winners" of this ancient saltern industry have for thousands of years relied upon the tides of the sea to fill evaporation pans. This salt industry is probably the only credible witness of historical fluctuations of the eustatic sea level and past climate change. Between the years $100 \mathrm{BCE}$ and $300 \mathrm{AD}$ the Mediterranean Sea level is estimated to have risen 1.8 meters. This is a sea-level rise indicating historic global warming similar to present estimated rates of rising. It also is evidence of catastrophic inundation and lack of salt supplies resulting in the development of the Silk Road as a source of the traded commodity salt, and the means of exchange which was silk.

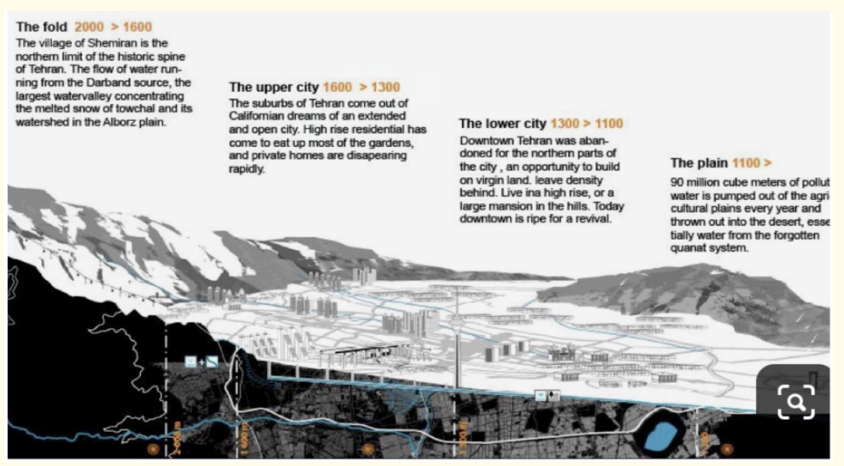

Figure 4: Typical Central Asia town founded upon a Qanat matrix of canals.

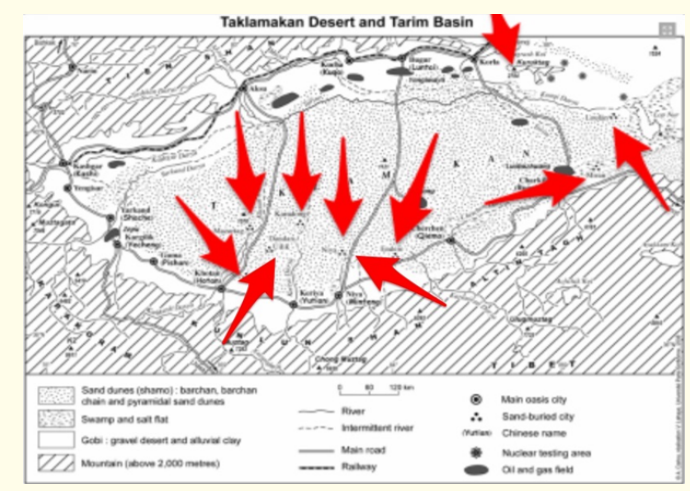

Figure 5: Ancient Silk Road Oasis leaching points - Today - Lop Nur potash salt factory.

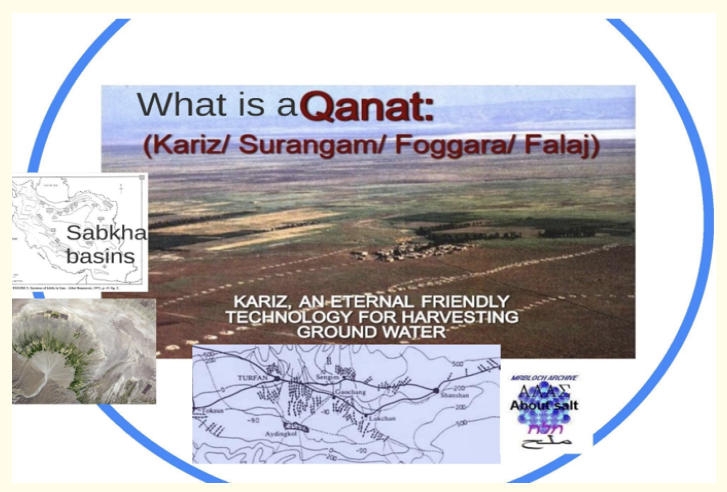

Figure 6: TURPAN in the Taklamakan desert [Tarim basin] and the many Qanat systems.

Thousands of kilometers of tunnels and boreholes were designed and built with very heavy human investment, primarily to leach, dissolve and recrystallize salts - predominantly sodium chloride. They were only limited in capacity by the Qanat volumetric capacity watershed flow into the endorheic basins needed to extract these salts. Timed leaching of the florescent topsoil during short surge flooding ensured shallow evaporation conditions. Today we know that in addition nature has continuously supplied these basins with huge rich mineral waters, which in many cases lurks only a few meters in the water table below the basin surface. In the Tarim basin, a Potash salt production unit is today pumping these brines to produce industrial Potassium salt fertilizer, using the Qanat Karez technology. The ancient Qanat water distribution design to leach salt is thought to have operated by controlled flooding of the "fields" in such endorheic basin flat alluvial expanses. The Qanat tunnel volume was seasonally flooded including in huge cisterns to provide volumetric surge capacity. At the appropriate moment, the volume of water stored in these cisterns and the tunnels were manually released to "well" and to gush up through multiple bore-holes in the flat basin surface, dissolving the sub-florescent capillary salts to create a rich brine "irrigating' the surrounding evaporation fields. As the brine became concentrated, the salts re-crystallized and precipitated at their designated point of supersaturation. The resulting crust of pure layered salts depended upon the flood timing controls of the Qanats using leather water bag valves to open and close the Qanat conduits. Thus a controlled shallow brine level in surrounding flat fields optimally dissolved 
Reverse Engineering of Arable Agriculture: The Technique of Tilling and Plowing as an Erroneous Development from the Ancient Technology of Field Desalination of Endorheic Basin Florescent Top-Soils to Produce Playa Salt Cake Employing Qanat Falaj Karez Irrigation Systems

subsoil salt without eroding the flat basin surface to allow brine evaporation and eventually precipitation of a layer of white pristine salt. These slabs of salt were traded along the Spice route aka; the Silk Road.

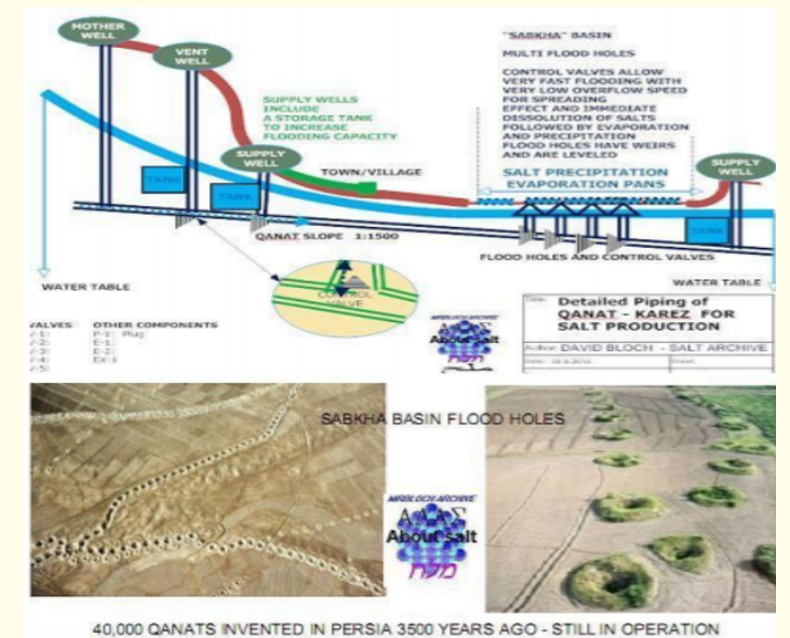

Figure 7

Many Qanat systems were additionally built under the pyramids whether regular or inverted step type. Thus an argument can be made that pyramids were built to enable irrigated hydroponic agriculture probably using only the sand from the surrounding desert to "hold" plants as they were irrigated with minimum quantities of water [1-11].

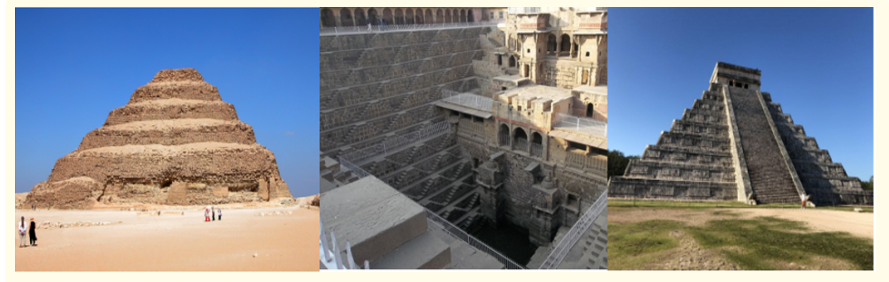

Figure 8: Step and inverted pyramids - were arid zone designs for aquaponics and hydroponics?

\section{Conclusion}

Today's ridge and furrow agriculture is no longer acceptable due to many problems, but particularly because spate irrigation causes huge water losses and salt concentration by capillary action. It has been assumed that such flooding irrigation could continue to be used in desert arid zones reducing the salt. However, it has now become clear that the agriculture of desalination to produce crusts of salt at a period of salt famine, was the initial purpose of the high investment in Qanat irrigation systems and their protecting Great Wall of China for which the Silk Road is famed. This ancient technology is surely destined for leaching and producing other important salts such as lythium, boron, and many other future rare earth materials rather than wasteful marginal agricultural and horticultural products in inappropriate deserts.

\section{Bibliography}

1. David Bloch. "Heavy saline streams in salt driven wetlands, abandoned evaporation pans, domes and other salt deposits as the responsible hydraulic mechanisms causing the disappearance of heavy waste liquids, and other waste toxic sediments on land and in the oceans D". Proceedings of the 2nd International Conference on the Ecological Importance of Solar Saltworks (CEISSA 2009) Merida, Yucatan, Mexico (2009).

2. Bloch R and M Reiner. "The mechanism of dissolution of salt crystals". Bulletin of the Research Council of Israel 2 (1952): 263-265.

3. Bloch MR., et al. "Ion separation in bursting air bubbles". Nature 209 (1966): 802-803.

4. Bloch MR and W Luecke. "The origin of fixed nitrogen in the atmosphere". Israel Journal of Earth Sciences 19 (1970): 41-49.

5. Bloch MR and W Luecke. "Geochemistry of ocean water bubble spray". Journal of Geophysical Research 77 (1972): 510051005.

6. Farkas L., et al. "The formation of "Salt Tables" in natural and artificial solar pans". Bulletin of the Research Council of Israel 1(1951): 36-39.

7. Hirosh Tamiya. "Growing Chlorella for food and feed". Proceedings World Symp. on Appl Solar Energy, Phoenix, Arizona (1955).

8. Muller A and W Schwarz 1948/49.

9. Radzisewski B von. Szasop, Towarz aptek. (Lwoff) 7 (1878): 249.

10. Welte DH. "Relation between petroleum and source rock". Bulletin American Association of Petroleum Chemistry 49 (1965): 2247-2268.

11. Bloch Garti., et al. "Conversion of halophilic algae into extractable oil 2 Pyrolysis of proteins". FUEL (1981).

\section{Volume 3 Issue 12 December 2019 (C) All rights are reserved by David Bloch.}

